\title{
ASSOCIATION BETWEEN KNOWLEDGE, FAMILY SUPPORT, AND ANTENATAL CARE, IN PREGNANT WOMEN AT PANEROKAN COMMUNITY HEALTH CENTER, BATANGHARI DISTRICT, JAMBI
}

\author{
Sri Mulyani, Herwansyah, Widya Rivani \\ Faculty of Medicine and Health Sciences, Universitas Jambi
}

\begin{abstract}
Background: Having a healthy pregnancy is one of the best ways to promote a healthy birth. Getting early and regular prenatal care improves the chances of a healthy pregnancy. This care can begin even before pregnancy with a preconception care visit to a health care provider. Despite various efforts by the Government of Indonesia, utilization of antenatal care (ANC) services continues to be low among women from rural areas particularly those belonging in Jambi. This study aimed to investigate the association between knowledge, family support, and antenatal care, in pregnant women at Panerokan community health center, Batanghari District, Jambi.
\end{abstract}

Subjects and Method: This was a cross-sectional study conducted at Penerokan Community Health Center, Batanghari, Jambi, in 2017. A sample of 97 pregnant mothers was collected by accidental sampling. The dependent variable was ANC visit. The independent variables were knowledge about ANC and family support. The data were collected by questionnaire and analyzed by Spearman rho.

Results: $45.4 \%$ pregnant mothers had good knowledge about ANC. 74.2\% received strong family support. $67 \%$ attended antenatal care regularly. Antenatal care visit was positively associated with maternal knowledge $(\mathrm{r}=0.39 ; \mathrm{p}<0.001)$ and family support $(\mathrm{r}=0.24 ; \mathrm{p}=0.019)$.

Conclusion: Antenatal care visit is positively associated with maternal knowledge and family support.

Keywords: antenatal care, knowledge, family support, pregnant women

\section{Correspondence:}

Sri Mulyani. Faculty of Medicine and Health Sciences, Universitas Jambi, Jambi, Indonesia. Email: yani_jogjam@yahoo.co.id. Mobile: 08192584448.

Mid-International Conference in Public Health, Best Western Premiere Hotel, Solo, Indonesia, 18-19 April 2018 | 208 https://doi.org/10.26911/mid.icph.2018.03.44 